Wilfrid Laurier University

Scholars Commons @ Laurier

Philosophy Faculty Publications

Philosophy

Winter 2002

\title{
Physicalism, Supervenience, and Dependence: A Reply to Botterell
}

Neil Campbell

Wilfrid Laurier University, ncampbell@wlu.ca

Follow this and additional works at: https://scholars.wlu.ca/phil_faculty

\section{Recommended Citation}

Campbell, Neil, "Physicalism, Supervenience, and Dependence: A Reply to Botterell" (2002). Philosophy Faculty Publications. 4.

https://scholars.wlu.ca/phil_faculty/4

This Article is brought to you for free and open access by the Philosophy at Scholars Commons @ Laurier. It has been accepted for inclusion in Philosophy Faculty Publications by an authorized administrator of Scholars Commons@Laurier. For more information, please contact scholarscommons@wlu.ca. 


\section{Physicalism, Supervenience, and Dependence: A Reply to Botterell}

NEIL CAMPBELL Wilfrid Laurier University

Andrew Botterell (this volume) has offered a fine response to my article, "Supervenience and Psycho-Physical Dependence" (Campbell 2000). In my original article, I argued that Donald Davidson's brand of supervenience should be understood as a relation between predicates rather than properties, that this formulation captures a form of psycho-physical dependence that eludes other forms of supervenience, and that, as such, it might be useful to revisit Davidsonian supervenience as a means of expressing a plausible form of physicalism. Botterell's reply centres on offering support for the following two claims: (1) that the distinction between properties and predicates "is irrelevant to issues concerning physicalism and supervenience" (Botterell 2002, p. 155); and (2) that predicate supervenience ${ }^{1}$ is unhelpful to formulating a plausible form of physicalism. I think the first claim is false, but not for reasons that are readily apparent in the original article. My reaction to the second claim is more complicated. ${ }^{2}$

My main reason for thinking (1) is false stems from concerns I have addressed elsewhere (Campbell 1997, 1998) and touched on only obliquely in the article to which Botterell replies. Briefly, I have argued that drawing a distinction between properties and predicates in Davidson's formulation of supervenience goes a long way to insulating him from the objection that anomalous monism entails epiphenomenalism. This objection, so frequently raised against Davidson, ${ }^{3}$ states that because strict laws are couched in physical terms, a mental event has the causal

Dialogue XLI (2002), 163-67

(C) 2002 Canadian Philosophical Association/Association canadienne de philosophie 
powers it does only in virtue of its physical properties. Hence, mental properties do no causal work in which case anomalous monism entails type-epiphenomenalism. I have argued that Davidson conceives of supervenience as a relation between predicates rather than properties, in which case the objection is misguided. If mental properties are not understood as ontological constituents of events, then it makes little sense to describe such properties as epiphenomenal. If this reply works, the propertypredicate distinction is crucial to regarding supervenience (Davidson's version, anyway) as a form of physicalism. Few physicalists are willing to accept epiphenomenalism as a palatable theory, so, contrary to Botterell's first claim, it would seem that the distinction between properties and predicates is, at least in the context of discussions between Davidson and his critics (especially Kim), central to the issues Botterell mentions.

My suspicion is that Botterell did not actually intend to assert (1). I do not imagine he meant to say that the mentioned distinction is irrelevant to issues concerning physicalism and supervenience, but that the distinction is no help to formulating a version of supervenience that captures a meaningful sense of psycho-physical dependence, one that would be helpful to physicalism. So, let us turn to the following two questions, which I will treat as subsumed under Botterell's second objection above: (A) does predicate supervenience express a form of psycho-physical dependence? and if so, (B) is this form of dependence enough to give physicalists what they need? Botterell answers no to both these questions.

(A) Does predicate supervenience express a form of psycho-physical dependence?

According to Botterell, we are no better off formulating supervenience as a relation between predicates rather than properties because the very same objections to property supervenience hold for predicate supervenience:

Since replacing talk of properties with talk of predicates does not affect the modal force of the relevant supervenience theses, any problems with a given property supervenience will carry over without residue to the corresponding predicate supervenience thesis. (Botterell 2002, p. 158)

To support this, Botterell points out that in the case of weak predicate supervenience, two individuals in different worlds who are ascribed the same physical predicates could be ascribed different mental predicates (Botterell 2002, p. 159), and that even within one possible world, predicate supervenience cannot handle creatures like zombies (Botterell 2002, p. 160). These possibilities should be precluded if predicate supervenience really expresses psycho-physical dependence. 
The main thing that strikes me about Botterell's worries is his focus on the modal force of predicate supervenience. In one sense this is fine and expected, for it is consistent with the way of thinking about supervenience that $\operatorname{Kim}(1987,1990,1993 a$, b) has encouraged. However, to do so fails to take seriously the deep difference between Davidson's and Kim's understanding of the concept. In my earlier article, I tried to emphasize that Davidson's thesis should not be regarded as a metaphysical thesis but as a kind of pragmatic thesis, one that describes our linguistic practices in our daily interactions with objects and events. To introduce modal concerns into this framework seems to me inappropriate, for doing so attempts to turn a pragmatic thesis into a metaphysical one. We must be careful to remember that for Davidson events are mental only as described. What counts as mental and how it is related to the physical is therefore not a metaphysical matter of the way properties or predicates are distributed among possible worlds: it is a matter of how, in this world and in our practices, we talk about ourselves and each other. Given this, it seems only fair to limit our discussion of supervenience to the contexts in which these practices actually occur. Hence, to insist that the same modal concerns that hold for other forms of supervenience are also a problem for Davidson's version is plausible only if one has failed to appreciate the deep differences between Davidson's and Kim's versions.

When understood in this light, does predicate supervenience describe a relation of dependence? I believe so. As I stated in the original article, the mental predicates we ascribe to one another are dependent on, and determined by, what we take to be physical facts about each other and the environment. Behaviour and physical circumstances must always serve as the starting point for interpretation. If the behaviour or circumstances change, we alter our mental ascriptions. This is a straightforward kind of dependence, but does this kind of dependence suffice for physicalism?

(B) Is this form of dependence enough to give physicalists what they need?

The answer to this question depends on our assessment of what is needed for physicalism. Although a proper exploration of this issue far exceeds the scope of this reply, I will venture to offer a few brief thoughts.

It is often said that the dependence of the mental on the physical is the bare minimum that is required for physicalism since this would mean that the physical facts determine all the facts. If this is correct, then it seems to me that predicate supervenience suffices since physical facts determine the mental ascriptions we offer. Of course, this means that physicalism is a thesis about $u s$, not about other possible beings in other possible worlds. Nor is it a thesis about what is metaphysically necessary. This is not a very ambi- 
tious or sexy thesis. It is, as I quoted Davidson in my previous article, a "bland monism" (Davidson 1970, p. 214)—about as bland as one can get.

While I think psycho-physical dependence is enough, many philosophers want something more. Like Kim, they insist on a modally reinforced thesis that does or does not allow for the existence of purely spiritual beings, and that invokes variously weak or strong versions of logical, physical, and metaphysical necessity. These are all interesting notions and the discussions that surround them are profound and complex. If, in fact, these and other such concepts are required for physicalism, then Botterell is correct: the Davidsonian version will not suffice and we will have to look to other approaches. However, I cannot help but wonder if these kinds of physicalists have confused what they need with what they want.

\section{Notes}

1 This is Botterell's locution, not mine.

2 I should preface this reply by pointing out that, although Botterell attributes the form of supervenience outlined in my original article to me, my aim in that article was to clarify what I take to be Davidson's understanding of supervenience and what its advantages might be. I am not sure $I$ want to follow Davidson in his treatment of physicalism for a variety of reasons, but I think we ought at least to take the approach he suggests seriously.

3 For a sampling, see Antony (1989), Bilodeau (1993), Hess (1981), Honderich (1982, 1983, 1984), Horgan (1989), Kim (1993a), Klagge (1990), and Stoutland $(1980,1985)$.

\section{References}

Antony, L.

1989 "Anomalous Monism and the Problem of Explanatory Force." Philosophical Review, 98: 153-87.

Bilodeau, R.

1993 "L'Inertie du Mental." Dialogue: Canadian Philosophical Review, 32: 507-24.

Botterell, A.

2002 "Physicalism, Supervenience, and Dependence: A Reply to Campbell." Dialogue: Canadian Philosophical Review, 41, 1: 155-61.

Campbell, N.

1997 "The Standard Objection to Anomalous Monism." Australasian Journal of Philosophy, 73, 3: 373-82.

1998 "Anomalous Monism and the Charge of Epiphenomenalism." Dialectica, 52, 1: 23-39.

2000 "Supervenience and Psycho-Physical Dependence." Dialogue: Canadian Philosophical Review, 39: 303-16. 
Davidson, D.

1970 "Mental Events." In Experience and Theory. Edited by L. Foster and J. Swanson. Amherst, MA: University of Massachusetts Press.

Hess, P.

1981 "Actions, Reasons, and Humean Causes." Analysis, 40: 77-81. Honderich, T.

1982 "The Argument for Anomalous Monism." Analysis, 42: 59-64.

1983 "Anomalous Monism: Reply to Smith." Analysis, 43: 147-49.

1984 "Smith and the Champion of Mauve." Analysis, 44: 86-89.

Horgan, T.

1989 "Mental Quausation." Philosophical Perspectives, 3: 47-76.

$\mathrm{Kim}, \mathrm{J}$.

1987 “'Strong' and 'Global' Supervenience Revisited." Philosophy and Phenomenological Research, 48: 315-26.

1990 "Supervenience as a Philosophical Concept." Metaphilosophy, 21: $1-27$.

1993a "Can Supervenience and 'Non-Strict Laws' Save Anomalous Monism?" In Mental Causation. Edited by J. Heil and A. Mele. Oxford: Clarendon.

1993b "Concepts of Supervenience." In Supervenience and Mind. Edited by J. Kim. New York: Cambridge University Press, pp. 153-76.

Klagge, J.

1990 "Davidson's Troubles with Supervenience." Synthese, 85: 339-52.

Stoutland, F.

1980 "Oblique Causation and Reasons for Action." Synthese, 43: 351-67.

1985 "Davidson on Intentional Behavior." In Actions and Events: Perspectives on the Philosophy of Donald Davidson. Edited by E. Lepore and B. McLaughlin. New York: Basil Blackwell. 